\title{
Gas Chromatographic and Mass Spectrometric Characterization of Trimethylsilyl Derivatives of Some Terpene Alcohol Phenylpropenoids
}

\author{
Lech Szczepaniak, ${ }^{\dagger}$ Piotr WateJko, and Valery A. Isidorov \\ Institute of Chemistry, University of Bialystok, Hurtowa 1, Bialystok PL-15399, Poland
}

\begin{abstract}
This paper reports mass spectra and linear temperature programmed retention indices $\left(I^{\mathrm{T}}\right)$ for 31 esters of mono- and sesquiterpene alcohols with hydroxycinnamic acids. In this study, 14 phenylpropenoids were synthesized by esterification of terpenols with $p$-coumaric, ferulic, caffeic and sinapinic acids. Other phenylpropenoids were semi-quantitatively isolated by column chromatography from exudates covering the buds of two birch species (Betula pubescens and $B$. litwinowii). Main diagnostic ions in phenylpropenoids mass spectra were determined by GC/MS analysis. The possibility of predicting $I^{\mathrm{T}}$ values was demonstrated with standard error of prediction between 3 and 11 of retention index units.
\end{abstract}

(Received February 15, 2013; Accepted April 16, 2013; Published June 10, 2013)

\section{Introduction}

Esters of cinnamic acids with terpene alcohols belonging to phenolic substances were discovered rather late in the plant kingdom and, owing to this, are not sufficiently characterized both chromatographically as well as mass spectrometrically. The first discovered compound from this class of substances, geranyl $(E)$-p-coumarate, was identified in the buds of North American balsam poplar (Populus balsamifera). ${ }^{1}$ Later, the same authors found the second terpene phenylpropenoid, geranyl caffeate, in the exudate from Himalayan poplar $(P$. ciliate) buds, ${ }^{2}$ as well as in the poplar type propolis collected in Oxfordshire, UK. ${ }^{3}$ On the basis of the detailed study of propolis composition, the authors drew a conclusion that its plant precursor is an exudate of an American and European poplar species hybrid, widespread in England.

In the following years, evidence has been collected that phenylpropenoid esters are more widespread in plant exudates than it was assumed. In particular, $(Z)$ - and $(E)$-docosyl $p$-coumarate isomers were isolated from aerial parts of tubbak (Psiadia punctulata), a plant used in traditional medicine in tropical regions of Africa ${ }^{4}$ and ferulates of aliphatic alcohols with $\mathrm{C}$ numbers from 16 to 30 were also found in potato pulp. ${ }^{5}$ Recently, Russian authors ${ }^{6}$ isolated $p$-coumarates of 14-hydroxy$\beta$-caryophyllene, 6-hydroxy- $\beta$-caryophyllene, 14 -hydroxy- $\alpha$ humulene and 9,9-dimethyl-2,5-dimethylenebicyclo[6.2.0]decane4-methanol from silver birch (Betula pendula) buds, typical for the Eurasian continent. In the presented GC/MS studies of white birch (B. pubescens) and Litvinov birch (B. litwinowii) bud exudates, not only $p$-coumarates, but also a series of ferulates and caffeates of sesquiterpene alcohols of caryophyllane and humulane types were found. ${ }^{7}$

Cinnamic acids and their esters show different biological

$\dagger$ To whom correspondence should be addressed.

E-mail: lech@uwb.edu.pl activities. ${ }^{8-10}$ It was demonstrated that caffeates of two terpene alcohols (geraniol and farnesol) show an inhibitory effect on nitric oxide (which induces inflammation) production. These phenylpropenoids are also potential cytotoxic agents. Thus, they may exhibit antitumor activity. ${ }^{11}$ Indeed, in vitro experiments showed that synthetic esters of ferulic and caffeic acids have an ability to inhibit the development of colon, gastric and breast cancer cells. Apart from that, phenylpropenoids are active in lipid peroxidation inhibition and prevent DNA damage due to oxidation..$^{12}$ Because of the discovery of these properties, interest in natural phenylpropenoids and their synthetic analogues has grown in recent years. ${ }^{13-15}$

Therefore, the current aim is to characterize terpene alcohol phenylpropenoids by gas chromatography and mass spectrometry, and to predict their chromatographic retention index ${ }^{16}$ values when standards are not available. The material for this work are phenylpropenoids found in plant material, as well as their analogues synthesized especially for this purpose.

\section{Experimental}

\section{Chemicals}

Commercial $p$-coumaric, ferulic, caffeic and sinapinic acids, and terpene alcohols: nerol, geraniol and $(E, E)$-farnesol, as well as $n$-hexane, pyridine, oxalyl chloride, $1,1^{\prime}$-carbonyldiimidazole (CDI), 4- $N, N$-dimethylaminopyridine (DMAP) and bis(trimethylsilyl)trifluoroacetamide (BSTFA) containing $1 \%$ trimethylchlorosilane were purchased from Sigma-Aldrich (Poznań, Poland). Ethyl acetate, tetrahydrofuran (THF) and diethyl ether were purchased from POCH SA (Gliwice, Poland). Dry THF was obtained by distillation over $\mathrm{Na}$ /benzophenone.

\section{Synthesis of phenylpropenoid esters and their TMS derivatives}

The esterification reactions (Fig. 1) were performed under argon at room temperature using the Steglich procedure. ${ }^{17}$ The appropriate acid $(0.25 \mathrm{mmol}), \mathrm{CDI}(0.5 \mathrm{mmol})$ and catalytic 
amount of DMAP were stirred in freshly distilled THF $(4 \mathrm{~mL})$ for $10 \mathrm{~min}$ at room temperature. Then, the solution of corresponding terpene alcohol $(0.25 \mathrm{mmol})$ in dry THF $(2 \mathrm{~mL})$ was added. The resulting mixture was stirred overnight. The

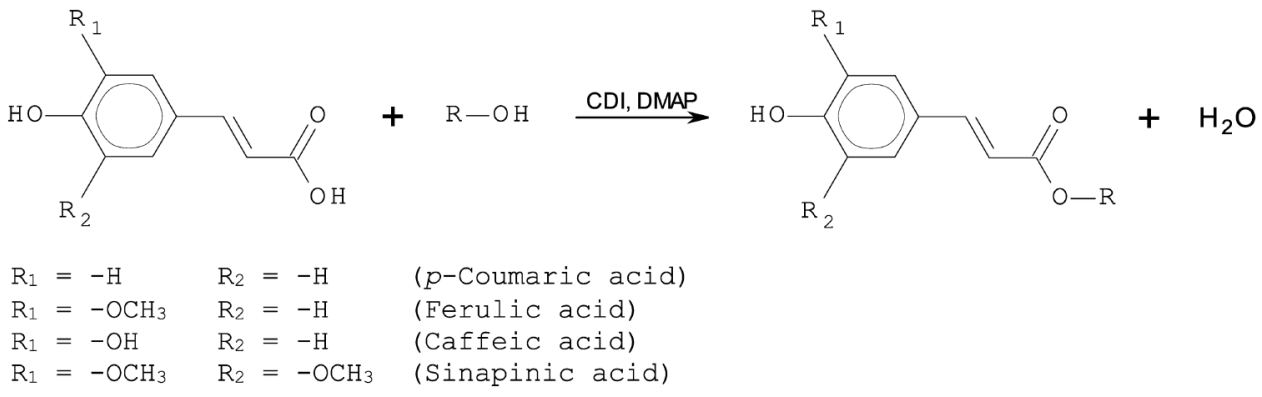

Fig. 1 Synthesis scheme and structures of p-coumarates, ferulates, caffeates and sinapinates of terpene alcohols.

(a)
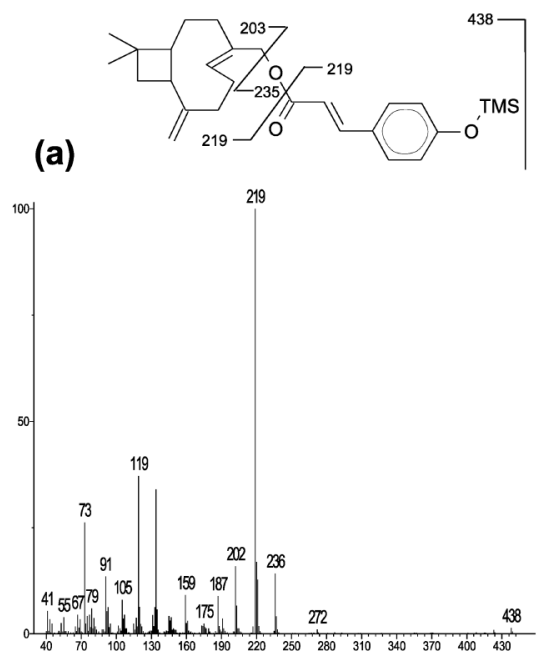

(b)
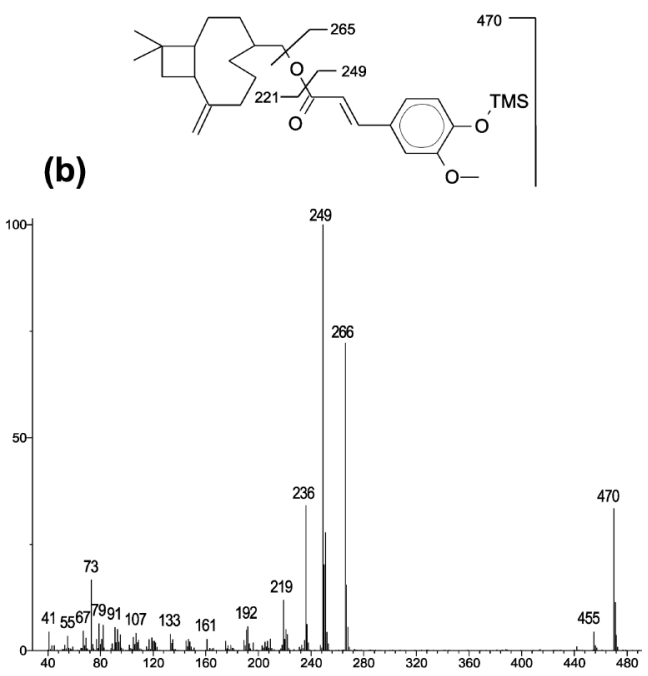

(d)

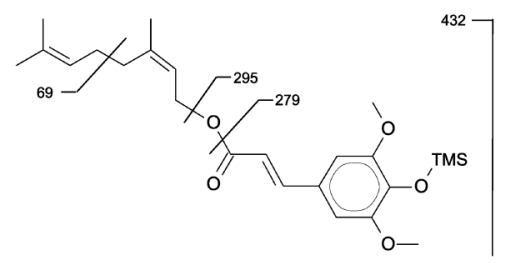

(c)
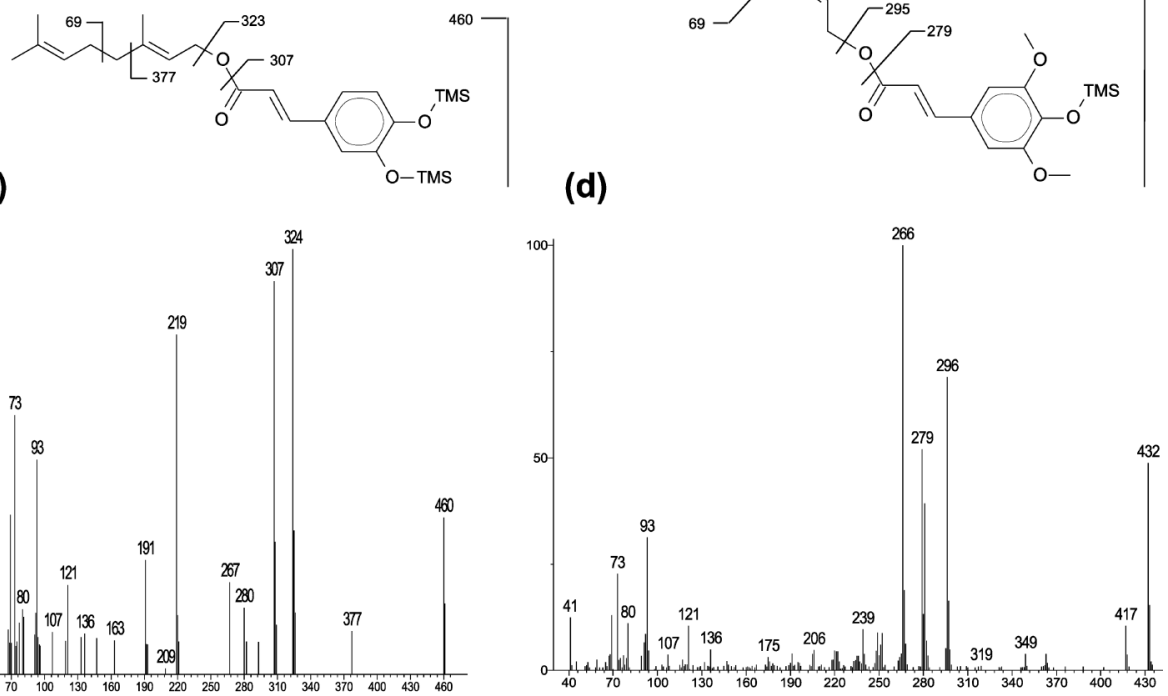

Fig. 2 EIMS spectra and main fragmentation patterns of phenylpropenoid terpenols: (a) TMS derivative of 14-hydroxy- $\beta$-caryophyllene $p$-coumarate, (b) TMS derivative of 14-hydroxy-4,5dihydro- $\beta$-caryophyllene ferulate, (c) TMS derivative of geranyl caffeate, (d) TMS derivative of neryl sinapinate. 
Table 1 Retention indices of the TMS derivatives of terpene alcohols and their phenylpropenoid esters

\begin{tabular}{|c|c|c|c|c|}
\hline Alcohol & Formula of ester & $\mathrm{MW}_{\text {ester }}$ & $I_{\text {alcohol }}^{\mathrm{T}}$ & $I_{\text {ester }}^{\mathrm{T}}$ \\
\hline \multicolumn{5}{|l|}{ Esters of $p$-coumaric acid } \\
\hline Myrtenol & $\mathrm{C}_{22} \mathrm{H}_{30} \mathrm{O}_{3} \mathrm{Si}$ & 370 & 1194 & 2634 \\
\hline Nerol & $\mathrm{C}_{22} \mathrm{H}_{32} \mathrm{O}_{3} \mathrm{Si}$ & 372 & 1229 & 2673 \\
\hline Geraniol & $\mathrm{C}_{22} \mathrm{H}_{32} \mathrm{O}_{3} \mathrm{Si}$ & 372 & 1255 & 2699 \\
\hline Caryophylladiene- $\beta$-ol ${ }^{\text {a }}$ & $\mathrm{C}_{27} \mathrm{H}_{38} \mathrm{O}_{3} \mathrm{Si}$ & 438 & 1635 & 3085 \\
\hline Caryophylladiene- $\alpha-$ ol $^{\text {a }}$ & $\mathrm{C}_{27} \mathrm{H}_{38} \mathrm{O}_{3} \mathrm{Si}$ & 438 & 1640 & 3091 \\
\hline 6-Hydroxy- $\beta$-caryophyllene & $\mathrm{C}_{27} \mathrm{H}_{38} \mathrm{O}_{3} \mathrm{Si}$ & 438 & 1682 & 3137 \\
\hline 14 -Hydroxy- $\beta$-caryophyllene $e^{\mathrm{a}, \mathrm{b}}$ & $\mathrm{C}_{27} \mathrm{H}_{38} \mathrm{O}_{3} \mathrm{Si}$ & 438 & 1707 & 3165 \\
\hline 14-Hydroxy- $\alpha$-humulene ${ }^{\mathrm{a}, \mathrm{b}}$ & $\mathrm{C}_{27} \mathrm{H}_{38} \mathrm{O}_{3} \mathrm{Si}$ & 438 & 1759 & 3210 \\
\hline$(E, E)$-Farnesol & $\mathrm{C}_{27} \mathrm{H}_{40} \mathrm{O}_{3} \mathrm{Si}$ & 440 & 1722 & 3172 \\
\hline 14-Hydroxy-4,5-dihydro- $\beta$-isocaryophyllene ${ }^{b}$ & $\mathrm{C}_{27} \mathrm{H}_{40} \mathrm{O}_{3} \mathrm{Si}$ & 440 & 1734 & 3190 \\
\hline 14-Hydroxy-4,5-dihydro- $\beta$-caryophyllene ${ }^{b}$ & $\mathrm{C}_{27} \mathrm{H}_{40} \mathrm{O}_{3} \mathrm{Si}$ & 440 & 1762 & 3220 \\
\hline \multicolumn{5}{|c|}{$I_{\text {ester }}=1414( \pm 6)+1.023( \pm 0.004) \cdot I_{\text {alcohol }}^{\mathrm{T}_{\text {al }}} ; n=11 ; R^{2}=0.9999 ; \mathrm{SE}=3 ; \mathrm{SEP}_{\mathrm{CV}-\mathrm{LOO}}=3$} \\
\hline \multicolumn{5}{|l|}{ Esters of ferulic acid } \\
\hline Nerol & $\mathrm{C}_{23} \mathrm{H}_{34} \mathrm{O}_{4} \mathrm{Si}$ & 402 & 1229 & 2806 \\
\hline Geraniol & $\mathrm{C}_{23} \mathrm{H}_{34} \mathrm{O}_{4} \mathrm{Si}$ & 402 & 1255 & 2831 \\
\hline Caryophylladiene- $\beta$-ol ${ }^{\mathrm{a}}$ & $\mathrm{C}_{28} \mathrm{H}_{40} \mathrm{O}_{3} \mathrm{Si}$ & 468 & 1635 & 3230 \\
\hline Caryophylladiene- $\alpha$-ol ${ }^{\text {a }}$ & $\mathrm{C}_{28} \mathrm{H}_{40} \mathrm{O}_{4} \mathrm{Si}$ & 468 & 1640 & 3234 \\
\hline 6-Hydroxy- $\beta$-caryophyllene ${ }^{\mathrm{a}}$ & $\mathrm{C}_{28} \mathrm{H}_{40} \mathrm{O}_{4} \mathrm{Si}$ & 468 & 1682 & 3279 \\
\hline 14 -Hydroxy- $\beta$-caryophyllene ${ }^{a}$ & $\mathrm{C}_{28} \mathrm{H}_{40} \mathrm{O}_{4} \mathrm{Si}$ & 468 & 1707 & 3305 \\
\hline 14-Hydroxy- $\alpha$-humulene ${ }^{\mathrm{a}, \mathrm{b}}$ & $\mathrm{C}_{28} \mathrm{H}_{40} \mathrm{O}_{4} \mathrm{Si}$ & 468 & 1759 & 3342 \\
\hline$(E, E)$-Farnesol & $\mathrm{C}_{28} \mathrm{H}_{42} \mathrm{O}_{4} \mathrm{Si}$ & 470 & 1722 & 3293 \\
\hline 14-Hydroxy-4,5-dihydro- $\beta$-caryophyllene ${ }^{\mathrm{b}}$ & $\mathrm{C}_{28} \mathrm{H}_{42} \mathrm{O}_{4} \mathrm{Si}$ & 470 & 1762 & 3346 \\
\hline \multicolumn{5}{|c|}{$I_{\text {ester }}^{\mathrm{T}}=1554( \pm 27)+1.020( \pm 0.017) \cdot I_{\text {alcohol }} ; n=9 ; R^{2}=0.9981 ; \mathrm{SE}=10 ; \mathrm{SEP}_{\mathrm{CV}-\mathrm{LOO}}=11$} \\
\hline \multicolumn{5}{|c|}{ Esters of caffeic acid } \\
\hline Nerol & $\mathrm{C}_{25} \mathrm{H}_{40} \mathrm{O}_{4} \mathrm{Si}_{2}$ & 460 & 1229 & 2871 \\
\hline Geraniol & $\mathrm{C}_{25} \mathrm{H}_{40} \mathrm{O}_{4} \mathrm{Si}_{2}$ & 460 & 1255 & 2896 \\
\hline 14-Hydroxy- $\beta$-caryophyllene ${ }^{a}$ & $\mathrm{C}_{30} \mathrm{H}_{46} \mathrm{O}_{4} \mathrm{Si}_{2}$ & 526 & 1707 & 3362 \\
\hline$(E, E)$-Farnesol & $\mathrm{C}_{30} \mathrm{H}_{48} \mathrm{O}_{4} \mathrm{Si}_{2}$ & 528 & 1722 & 3364 \\
\hline 14-Hydroxy-4,5-dihydro- $\beta$-caryophyllene ${ }^{\mathrm{b}}$ & $\mathrm{C}_{30} \mathrm{H}_{48} \mathrm{O}_{4} \mathrm{Si}_{2}$ & 528 & 1762 & 3412 \\
\hline \multicolumn{5}{|c|}{$I_{\text {ester }}^{\mathrm{T}}=1622( \pm 16)+1.015( \pm 0.010) \cdot I_{\text {alcohol }}^{\mathrm{T}} ; n=5 ; R^{2}=0.9997 ; \mathrm{SE}=5 ; \mathrm{SEP}_{\mathrm{CV}-\mathrm{LOO}}=7$} \\
\hline \multicolumn{5}{|c|}{ Esters of sinapinic acid } \\
\hline Nerol & $\mathrm{C}_{24} \mathrm{H}_{36} \mathrm{O}_{5} \mathrm{Si}$ & 432 & 1229 & 2986 \\
\hline Geraniol & $\mathrm{C}_{24} \mathrm{H}_{36} \mathrm{O}_{5} \mathrm{Si}$ & 432 & 1255 & 3012 \\
\hline$(E, E)$-Farnesol & $\mathrm{C}_{29} \mathrm{H}_{44} \mathrm{O}_{5} \mathrm{Si}$ & 500 & 1722 & 3465 \\
\hline
\end{tabular}

$\mathrm{SE}$, standard error; $\mathrm{SEP}_{\mathrm{CV}-\mathrm{LOO}}$, standard error of prediction (CV-LOO, cross validation method with leave-one-out).

a. Identified in the exudate from white birch (B. pubescens) buds. b. Identified in the exudate from Litvinov birch (B. litwinowii) buds.

solvent was evaporated to dryness and the residue was dissolved in ethyl acetate, washed with $\mathrm{NaHCO}_{3}$ and with water, dried over $\mathrm{MgSO}_{4}$, filtered with a Celite pad and concentrated in a stream of nitrogen. The crude product was dissolved in pyridine $(220 \mu \mathrm{L})$ in a vial $(2 \mathrm{~mL})$ and BSTFA $(80 \mu \mathrm{L})$ was added. This mixture was heated at $60^{\circ} \mathrm{C}$ for $0.5 \mathrm{~h}$. The obtained TMS derivatives were subjected to GC/MS analysis.

\section{Isolation of sesquiterpene phenylpropenoids from birch buds}

The buds of two birch species (Betula pubescens and $B$. litwinowii) were collected from an arboretum, owned by Institute of Dendrology, Polish Academy of Sciences. The $5 \mathrm{~g}$ of buds was dried at $40^{\circ} \mathrm{C}$, crushed and extracted by three portions $(25 \mathrm{~mL}$ each) of diethyl ether while stirring constantly. The joint extracts were dried over anhydrous $\mathrm{Na}_{2} \mathrm{SO}_{4}$, filtered through a paper filter and the solvent was removed to a volume of $c a .1 \mathrm{~mL}$ on a rotor evaporator. These extracts were subjected to GC/MS analysis. Then, they were fractionated by column chromatography on a silica column. Next, $n$-hexane was used to elute mixtures of non-polar and slightly polar compounds. Then, gradient elution ( $n$-hexane/ethyl acetate) was used to isolate fractions containing phenylpropenoid esters of terpene alcohols. In this study, we did not try to isolate a pure compound and the only task of using column chromatography was to obtain the fractions that contained compounds of interest. All the fractions were analyzed by GC/MS and, after solvent evaporation, those that contained phenylpropenoids were subjected to derivatization (as above).

\section{GC/MS analysis}

TMS derivatives isolated from birch buds and synthesized phenylpropenoids were analyzed on an Agilent 6890 gas chromatograph with a mass selective detector MSD 5973, which was fitted with an authosampler HP-7683, electronic pressure control and split/splitless injector. Separation was performed on an HP-5ms ( $30 \mathrm{~m} \times 0.25 \mathrm{~mm} ; 0.25 \mu \mathrm{m}$ film thickness $)$ fused silica column with helium flow rate of $1 \mathrm{~mL} / \mathrm{min}$. The injector worked in a split (1:50) mode; injector temperature was $250^{\circ} \mathrm{C}$. EIMS spectra were obtained at $70 \mathrm{eV}$ ionization energy, at the source temperature $230^{\circ} \mathrm{C}$ and that of quadrupole $150^{\circ} \mathrm{C}$. The MSD was set to scan $\mathrm{m} / \mathrm{z} 40-600$. Chromatograms were acquired using a linear temperature program from 50 to $320^{\circ} \mathrm{C}$ at $3^{\circ} \mathrm{C}$ per minute.

The hexane solution of $\mathrm{C}_{10}-\mathrm{C}_{40} n$-alkanes was separated under the above conditions. Linear temperature programmed retention indices $\left(I^{\mathrm{T}}\right)$ were calculated from the results for this mixture and for solutions of TMS derivatives of terpene alcohols and TMS derivatives of phenylpropenoids. 
Table 2 Results of the retention index values estimation for 14 -hydroxy- $\beta$-isocaryophyllene phenylpropenoid $\left(I^{\mathrm{T}}\right.$ alcohol $\left.=1723\right)$

\begin{tabular}{llcccr}
\hline \multicolumn{1}{c}{ Ester } & Formula & $\mathrm{MW}_{\text {ester }}$ & $\begin{array}{l}I_{\text {ester }}^{\mathrm{T}} \\
\text { calc. }\end{array}$ & $\begin{array}{l}I_{\text {ester }}^{\mathrm{T}} \\
\text { exp. }\end{array}$ & $\Delta I^{\mathrm{T}}$ \\
\hline $\begin{array}{l}\text {-Coumarate } \\
\text { Ferulate }\end{array}$ & $\mathrm{C}_{27} \mathrm{H}_{38} \mathrm{O}_{3} \mathrm{Si}$ & 438 & 3178 & 3177 & -1 \\
Caffeate & $\mathrm{C}_{28} \mathrm{H}_{40} \mathrm{O}_{4} \mathrm{Si}$ & 468 & 3312 & 3321 & 9 \\
\hline
\end{tabular}

Model: $I_{\text {ester }}^{\mathrm{T}}=b_{0}+b_{1} \cdot I^{\mathrm{T}}$ alcohol.

\section{Results and Discussion}

\section{Mass spectrometric characterization of phenylpropenoid esters}

Figure 2 presents EIMS spectra and fragmentation patterns of two phenylpropenoid esters (their TMS derivatives) found in the buds: 14-hydroxy- $\beta$-caryophyllene $p$-coumarate and 14-hydroxy4,5 -dihydro- $\beta$-caryophyllene ferulate, as well as synthesized geranyl caffeate and neryl sinapinate. The molecular ion was found in the spectra of all phenylpropenoids. The low-mass region of the spectra shows the ion at $\mathrm{m} / z 73$ (TMS group) and, with relatively low intensity, ions derived from fragmentation of terpene parts. Mass spectra of phenylpropenoid esters formed by acyclic terpene alcohols: nerol, geraniol and farnesol contain peaks at $\mathrm{m} / z 69\left(\mathrm{C}_{5} \mathrm{H}_{9}{ }^{+}\right)$, typical for EIMS fragmentation of these alcohols. Main diagnostic ions at $m / z, 219,249,279$ and 307 are derived from the phenylpropenoic moieties (as the result of ester bond cleavage) in the spectra of $p$-coumaroyl, feruloyl, sinapinyl and caffeoyl esters, respectively. The loss of acyloxy parts from $\mathrm{M}^{+}$with synchronous $\mathrm{H}$-rearrangement gives rise to additional characteristic ions at $\mathrm{m} / \mathrm{z}, 236,266,296$ and 324, with the intensity increasing in this order. Mass spectra of TMS derivatives of phenylpropenoid esters of terpene alcohols are presented in the supplementary information in the edition of this Journal.

Gas chromatographic characterization of phenylpropenoid esters Table 1 presents experimental values of retention indices for TMS derivatives of 11 terpenols ( 3 mono-, 8 sesquiterpenols) and 28 phenylpropenoid esters ( $11 p$-coumarates, 9 ferulates, 5 caffeates and 3 sinapinates). Despite the fact that the use of fused silica capillary columns with immobilized low- and medium-polar stationary phases allows for separation of highboiling polar compounds without preliminary derivatization, we chose to present the retention indices of silanized phenylpropenoids of terpenols. One of the reasons for this is the fact that chromatographic retention times $\left(t_{\mathrm{R}}\right)$ of high-boiling polar substances not subjected to derivatization are quite sensitive to fluctuations of separation conditions (temperature and carrier gas flow rate). Besides that, when low polarity stationary phases are used, polar substances are eluted from chromatographic columns in the form of quite wide peaks, which makes the accurate determination of $t_{\mathrm{R}}$ values difficult. Therefore, the values of chromatographic retention indices of such substances, even if determined in one laboratory, are characterized by a higher deviation than the analogous values of their derivatives. For example, analysis of birch bud extracts and fractions collected during their separation on a silica column results with $I^{\mathrm{T}}$ values of $1667 \pm 8(n=8)$ and $3152 \pm 18$ i.u. $(n=6)$ for non-silanized 14-hydroxy- $\beta$-caryophyllene and its $p$-coumarate ester, respectively, whereas for TMS derivatives of these compounds the $I^{\mathrm{T}}$ values are $1707 \pm 1 \quad(n=11)$ and $3165 \pm 3$ i.u. $(n=8)$, respectively.
The use of derivatization is convenient also because phenylpropenoids in natural objects such as plant tissue and propolis are parts of complex mixtures that contain a large number of polar substances of different classes. Successful analysis of such mixtures is possible only after derivatization of these substances..$^{7,18}$

It was interesting to examine the possibility of $I^{\mathrm{T}}$ value prediction for terpene phenylpropenoids (their TMS derivatives) that were not subject to the experiment. Table 1 contains the calculated coefficients of linear equation $I^{\mathrm{T}}$ ester $=b_{0}+b_{1} \cdot I^{\mathrm{T}}$ alcohol for all the groups of phenylpropenoids: $p$-coumarates, ferulates, caffeates and sinapinates. It is visible that equations with calculated values of coefficients $b_{0}$ and $b_{1}$ are characterized by low standard errors (SE) and standard errors of prediction $\mathrm{SEP}_{\mathrm{CV} \text {-LOO }}$ is in the range $3-11$ i.u. Table 2 contains the results of $I^{\mathrm{T}}$ value calculations for three phenylpropenoids of 14-hydroxy- $\beta$-isocaryophyllene for which the experimental values of $I^{\mathrm{T}}$ were determined but they were not used to calculate the coefficients in the above equations. It can be seen that the greatest deviation from experimental values for $p$-coumarates, ferulates and caffeates does not exceed 10 i.u. This accuracy is on the level of inter-laboratory deviation of experimental $I^{\mathrm{T}}$ values. Therefore, it is possible to predict retention indices of other numerous mono- and sesquiterpene alcohols phenylpropenoids with acceptable accuracy.

\section{Acknowledgements}

The authors would like to thank Kinga Nowak, MSc from the Institute of Dendrology, Polish Academy of Sciences, for providing the bud samples and identifying the plant material.

\section{Supporting Information}

The mass spectra of TMS derivatives of terpene alcohol phenylpropenoids. This material is available free of charge on the Web at http://www.jsac.or.jp/analsci/.

\section{References}

1. W. Greenaway and F. R. Whatley, J. Chromatogr., A, 1990, $519,145$.

2. W. Greenaway and F. R. Whatley, Phytochemistry, 1991, 30, 1887.

3. W. Greenaway, J. May, T. Scaysbrook, and F. R. Whatley, Z. Naturforsch., C, 1991, 46, 111.

4. B. F. Juma, A. Yenesew, J. O. Midiwo, and P. G. Waterman, Phytochemistry, 2001, 57, 571.

5. K. Yunoki, R. Musa, M. Kinoshita, H. Tazaki, Y. Oda, and M. Ohnishi, Biosci. Biotechnol. Biochem., 2004, 68, 2619.

6. D. N. Vedernikov, N. G. Galashkina, and V. I. Roshchin, Rastit. Resur., 2007, 43, 84.

7. V. A. Isidorov and L. Szczepaniak, J. Chromatogr., A, 2009, $1216,8998$.

8. G. A. Burdock, Food Chem. Toxicol., 1998, 36, 347.

9. A. H. Banskota, Y. Tezuka, and S. Kadota, Phytother. Res., 2001, 15, 561.

10. M. Lechner, P. Lirk, and J. Rieder, Semin. Cancer Biol., 2005, 15, 277.

11. K. Uwai, Y. Osanai, T. Imaizumi, S. Kanno, M. Takeshita, and M. Ishikawa, Bioorg. Med. Chem., 2008, 16, 7795.

12. B. Jayaprakasam, M. Vanisree, Y. Zhang, D. L. Dewitt, and 
M. G. Nair, J. Agric. Food Chem., 2006, 54, 5375.

13. S. M. Fiuza, C. Gomes, L. J. Teixeira, M. T. Girão da Cruz, M. N. D. S. Cordeiro, N. Milhazes, F. Borges, and M. P. M. Marques, Bioorg. Med. Chem., 2004, 12, 3581.

14. N. Celli, B. Mariani, L. K. Dragani, S. Murzilli, C. Rossi, and D. Rotilio, J. Chromatogr., B, 2004, 810, 129.

15. N. Celli, L. K. Dragani, S. Murzilli, T. Pagliani, and A.
Poggi, J. Agric. Food Chem., 2007, 55, 3398.

16. H. van Den Dool and P. D. Kratz, J. Chromatogr., A, 1963, $11,463$.

17. B. Neises and W. Steglich, Angew. Chem. Int. Ed. Engl., 1978, 17, 522.

18. I. Molnár-Perl, J. Chromatogr., A, 1999, 845, 181. 